\title{
The Linkage Between Entrepreneurship Education and Entrepreneurial Success for Young Entrepreneurs in Central Java Indonesia
}

\author{
Suripto $^{1}$, Hayyu Vidia Utami ${ }^{2}$, Ghanis Putra Widhanarto ${ }^{3}$ \\ \{ghanisputra@mail.unnes.ac.id $\left.{ }^{3}\right\}$ \\ Educational Technology, Universitas Negeri Semarang, Indonesia
}

\begin{abstract}
Entrepreneurship, as the identity of the younger generation, can promise income as a form of business early on. Entrepreneurship in education is instilled through the curriculum and the spirit of student entrepreneurship. The purpose of this article is to reveal the relevance of education in entrepreneurship and successful entrepreneurship for the younger generation in Central Java. The method used is descriptive qualitative study with the interpretation of data using charts or graphs that reveal the interrelationships between variables. The subject of this research is the young generation of secondary schools. Qualitative data analysis is presented to show results. The result of this study is that entrepreneurship education has a relationship with the success of entrepreneurship for the younger generation in the Central Java region. This youth is evidenced by the indepth identification of the success of young entrepreneurs in school. The implication of this article for the field of entrepreneurship is the internalization of entrepreneurial knowledge for the younger generation can be done early through learning in schools so that this method can open new discourses for other studies that will reveal curriculum objectives specifically about long-term economic benefits.
\end{abstract}

Keyword: Entrepreneurship Education, Entrepreneurial Success, Young Entrepreneurs

\section{Introduction}

Spirit of entrepreneurship in Indonesia is very rapidly developing, following the development of innovation in the field of technology. This innovation is related to the rise of marketplaces [1] or social media based entrepreneurs [2], [3] that run efficiently to obtain internet connection facilities in Indonesia. Indonesia is a developing country with the second largest number of young entrepreneurs, as shown by economic data [4], the largest being the agricultural sector. The progress of this commercial sector had had a significant impact on the entrepreneurial behavior of the people in Indonesia. In line with the economic movement, more and more small businesses are also carried out with low capital.

The influence of free trade [5] with its regulations has a positive impact on entrepreneurs in Indonesia. With the development of entrepreneurs in Indonesia, it can be said that there is an influence of the entrepreneurial spirit that can develop entrepreneurial behavior for the 
younger generation [6], [7]. This youth is closely related to the activities of students with curriculum education in schools. The application of innovative curriculum education [8] can make students have a passion for entrepreneurship, also bring positive relations with stakeholders. Students have careful planning for achieving maximum entrepreneurial results so that they have a passion for earning income [9].

The research report [10] shows that the younger generation has excellent potential in running entrepreneurship in the present. Also, it was stated [11] that young entrepreneurs in Scotland between 1996 and 1998 were dominated by the younger generation. Other studies [12] report that entrepreneurship education in Malaysia effectively increases the impact of young entrepreneurial growth. Related research shows that young entrepreneurs have a significant influence on economic development in developed countries.

A study [13] says that Canadian statistics have 4 percent or a total of individual entrepreneurs who are under 25 years of age or about 23 percent of adolescents are under 35 years. So, in other words, more than 326,000 independent entrepreneurs can be classified as young entrepreneurs. In addition [10] in his research shows that entrepreneurial orientation can be encouraged by using specific targets, can be through the educational process [14], applied directly in the environment, and collaboration [15] with students in school through promotional activities. Significant influence can be obtained through the curriculum process implemented at the school. The curriculum can encourage student entrepreneurship orientation using a definite target model.

This research is different from other articles because it reveals the relevance of the curriculum with the results of young entrepreneurs [16]. This research answers previous studies on the impact of entrepreneurship on the economy by examining the most fundamental aspects, namely in the field of education. The purpose of this article is to uncover the relationship between entrepreneurship education and entrepreneurship success for the younger generation [17] in Central Java from the aspects of TACT (Target, Action, Context, and Time) [18]. The benefits of this article reveal the study that entrepreneurial education can bring students to become successful entrepreneurs in the location of central Java in Indonesia.

\section{Method}

method used is descriptive qualitative by [19], [20], data collection techniques with questionnaires that reveal the TACT aspects (target, action, context, time) model used [21], qualitative data analysis techniques using scale performance Likert [22] of variables compiled by data tabulation.

\section{Result and discussion}

The results of the questionnaire, which revealed the relevance of entrepreneurial education with successful entrepreneurship based on table 1 were focused on four variables of entrepreneurial goals, entrepreneurial implementation, context, and time of entrepreneurship. 
Table 1 variable table questionnaires

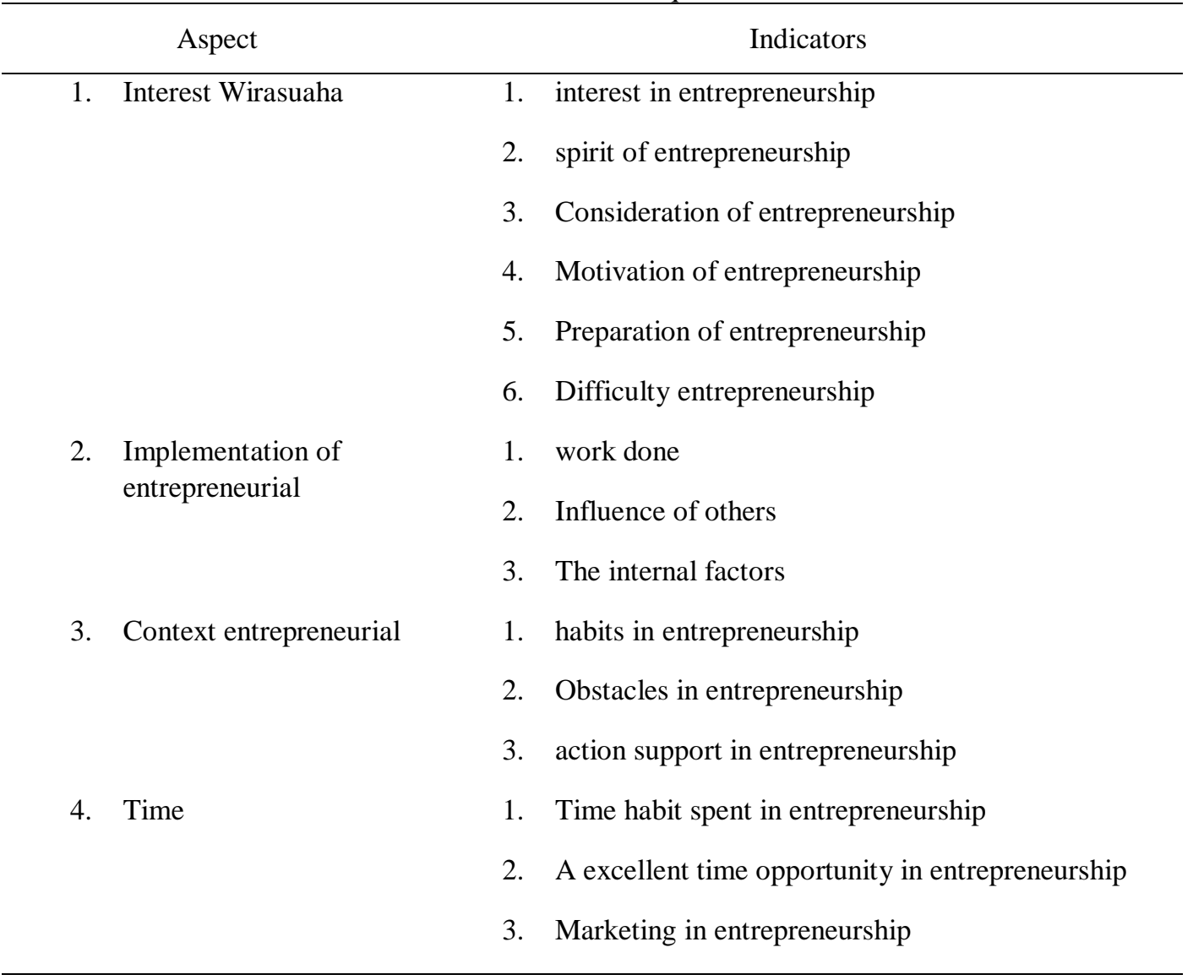

Referring to table 2, the distribution of respondents to young entrepreneurs in Central Java consisting of high school students is $30 \%$ for men and $70 \%$ for women.

Table 2 the frequency of respondents

\begin{tabular}{lcc}
\multicolumn{1}{c}{ Gender } & $\begin{array}{c}\text { Number of } \\
\text { Respondents }\end{array}$ & $\begin{array}{c}\text { Percenta } \\
\text { ge of }\end{array}$ \\
\hline Men & 3 & $30 \%$ \\
Women & 7 & $70 \%$ \\
& Total & $100 \%$ \\
\hline
\end{tabular}

Interest from young entrepreneurs is shown in table 3, namely the number of young people who are interested in the entrepreneurship class.

Table 3 interest in entrepreneurship

\begin{tabular}{lll}
\hline Response & Scale & Percentage of \\
\hline validity & Very low & $0 \%$ \\
& Low & $20 \%$ \\
\hline
\end{tabular}




\begin{tabular}{ll}
\hline Enough & $10 \%$ \\
High & $70 \%$ \\
\hline
\end{tabular}

Table 4 shows the curriculum material relevant to entrepreneurial activities and student ideals. From graphic design, subjects can be obtained an interest in entrepreneurship with many goals.

Table 4 distribution of subjects related to entrepreneurship

\begin{tabular}{lll}
\hline Subjects & Matter & Target Business \\
\hline Graphic & Photography & Photographers \\
Design & Graphic Design & Printing \\
& & Designers freelance \\
\hline
\end{tabular}

The linkage between education entrepreneurs with successful entrepreneurship for young people has been investigated by several experts expressed [17] that the younger generation is more creative in making business themes. It was also said [23] besides continuing education in schools, the business activities of the younger generation were also supported by the family. Another report [16] that the younger generation is very aspirational in business competition. [5] also reports that classroom practices about entrepreneurship can increase business success for the younger generation.

The condition of the younger generation in schools has a high entrepreneurial spirit, indicated by the existence of entrepreneurial material that is integrated into the subjects. This material can create entrepreneurial goals with a variety of different themes, such as photography, graphic design, and other freelance ideas. The conditions in Central Java in Indonesia have been relevant to many research results from various countries, so this study has no resistance.

\section{Conclusion}

Conclusions of this article are the statement that entrepreneurship education is linked to successful entrepreneurship, with some of the variables studied to reveal the association.

\section{References}

[1] M. C. Pantea, "You Can Change the World": Young People and Youth Organizations Becoming Entrepreneurial', Young, 2018.

[2] R. L. Afutu-Kotey, K. V. Gough, and G. Owusu, 'Young Entrepreneurs in the Mobile Telephony Sector in Ghana: From Necessities to Aspirations', J. African Bus., 2017.

[3] G. Owusu and R. L. Afutu-Kotey, 'Poor urban communities and municipal interface in Ghana: A case study of Accra and Sekondi-Takoradi metropolis', African Stud. Q., 2010.

[4] R. N. Ridha and B. P. Wahyu, 'Entrepreneurship intention in agricultural sector of young generation in Indonesia', Asia Pacific J. Innov. Entrep., vol. 11, no. 1, pp. 7689, 2017. 
[5] A. Cretella, 'Urban food strategies. Exploring definitions and diffusion of European cities' latest policy trend', in Research in Rural Sociology and Development, 2016.

[6] L. F. Edelman, T. S. Manolova, and C. G. Brush, 'Entrepreneurship education: Correspondence between practices of nascent entrepreneurs and textbook prescriptions for success', Acad. Manag. Learn. Educ., 2008.

[7] P. B. Robinson and E. A. Sexton, 'The effect of education and experience on selfemployment success', J. Bus. Ventur., 1994.

[8] N. Alfirević, J. Pavičić, and R. Relja, 'School management innovation and principal support systems: Toward the agenda for Croatian school reform', Econ. Res. Istraz. , 2016.

[9] J. Sitthisomjin, K. Somprach, and S. Phuseeorn, 'The effects of innovation management on school performance of secondary schools in Thailand', Kasetsart Journal of Social Sciences, 2018.

[10] F. Silva, G. Couto, and H. Coelho, 'Entrepreneurial Potential in the Younger Generation', J. Small Bus. Entrep., 2012.

[11] R. Henderson and M. Robertson, 'Who wants to be an entrepreneur? Young adult attitudes to entrepreneurship as a career', Educ. + Train., 1999.

[12] Z. Mohamed, G. Rezai, M. N. Shamsudin, and M. M. az Mahmud, 'Enhancing young graduates' intention towards entrepreneurship development in Malaysia', Educ. Train., 2012.

[13] J. Lorrain and L. Raymond, 'YOUNG AND OLDER ENTREPRENEURS: AN EMPIRICAL STUDY OF DIFFERENCE', J. Small Bus. Entrep., 1991.

[14] S. Borg, I. Clifford, and K. P. Htut, 'Having an EfECT: Professional development for teacher educators in Myanmar', Teach. Teach. Educ., 2018.

[15] E. J. Instefjord and E. Munthe, 'Educating digitally competent teachers: A study of integration of professional digital competence in teacher education', Teach. Teach. Educ., 2017.

[16] C. Conway, 'Supporting young entrepreneurs', International Journal of Entrepreneurship and Innovation. 2014.

[17] L. A. Zampetakis, M. Gotsi, C. Andriopoulos, and V. Moustakis, 'Creativity and Entrepreneurial Intention in Young People', Int. J. Entrep. Innov., 2011.

[18] L. Beck and I. Ajzen, 'Predicting dishonest actions using the theory of planned behavior', J. Res. Pers., 1991.

[19] J. W. Creswell, Educational Research: Planning, Conducting and Evaluating Quantitative and Qualitative Research. London: Pearson, 2012.

[20] J. W. Creswell, 'Research design: Qualitative, quantitative, and mixed methods approaches (3rd ed)', Res. Des. Qual. Quant. Mix. methods approaches, 2009.

[21] R. V. Mathew and N. Panchanatham, 'An exploratory study on the development of women entrepreneurs: Indian cases', J. Res. Mark. Entrep., vol. 18, no. 2, pp. 232 247, 2016.

[22] Y. Inoue and S. T. Bell, Teaching with educational technology in the 21st century: The case of the Asia-Pacific region. 2005.

[23] F. Crecente-Romero, M. Giménez-Baldazo, and L. F. Rivera-Galicia, 'Can entrepreneurship channel overqualification in young university graduates in the European Union?', J. Bus. Res., 2018. 